Review

\title{
Aggregates grain size and press rate dependence of the shielding parameters for some concretes
}

\author{
K.A. Mahmoud ${ }^{\mathrm{a}, \mathrm{b}, *}$, O.L. Tashlykov ${ }^{\mathrm{a}}$, A.F. El Wakil ${ }^{\mathrm{b}}$, I.E. El Aassy ${ }^{\mathrm{b}}$ \\ ${ }^{a}$ Ural Federal University, Yekaterinburg, 620002, Russia \\ ${ }^{\mathrm{b}}$ Nuclear Materials Authority. P. O. Box 530, El Maadi, Cairo, Egypt
}

\section{A R T I C L E I N F O}

\section{Keywords:}

Attenuation coefficient

Basalt concretes

Shielding parameters

Press rate

XCOM

\begin{abstract}
A B S T R A C T
This study points to evaluate the effect of crushed basalt grain size and the press rate on gamma ray shielding properties for some concretes. Nine different concretes were made up of $75 \%$ basalt, $25 \%$ Portland cement and drops of sodium meta silicate. Three concretes were performed with an average grain size varied between 25 and $107 \mu \mathrm{m}$. The other six concretes were performed under different press rate varied between $1.01 \mathrm{and} 142.76 \mathrm{~kg} /$ $\mathrm{cm}^{2}$ using a hydraulic press. The mass attenuation coefficient $\left(\mu_{\mathrm{m}}\right)$ of the prepared concretes was measured using the narrow beam transmission method using a hyper pure germanium detector at gamma ray energies 661.6, 1173.2, 1332.5, 121.8, 244.7, 344.3, 778.9, 964, 1112, $1408 \mathrm{KeV}$ emitted by point sources ${ }^{137} \mathrm{Cs}$, ${ }^{60} \mathrm{Co}$ and ${ }^{152} \mathrm{Eu}$. Other important shielding parameters such as half value thickness and radiation protection efficiency were calculated for the prepared concretes at different energies. The obtained experimental data was compared with theoretical data obtained from XCOM program. The results showed that the mass attenuation coefficient was decreased with energy increase, but it increases with grain size decrease. The obtained results showed also that the mass attenuation enhanced by increasing the pressure rate.
\end{abstract}

\section{Introduction}

The use of radioactive applications has been increased exponentially in the last few decades. Radioactive isotopes were used in a lot of fields such as nuclear research, medicine, industry and agriculture. Using these radioactive isotopes can cause dangerous damage of the workers and exposures tissues (Gençel et al., 2010; Mann et al., 2016). For radiation protection inside houses, factories and hospitals, the building materials used must provide adequate protection for workers at a reasonable cost (Bashter et al., 1996). The mass attenuation coefficient provides information about gamma ray penetration and the amount of energy deposited inside the exposed materials. Lead and concretes were considered as gamma rays shielding materials.

Many studies have been performed on the measurement of linear and mass attenuation coefficient for different concretes which can be used as radiation shielding (Akkurt et al., 2004; Bashter, 1997; Y1lmaz, et al., 2011; El-Sayed Abdo, 2002; Gencel et al., 2011; Kharita et al., 2008; Rezaei-Ochbelagh and Azimkhani, 2012; Shirmardi et al., 2013; Singh et al., 2004, 2015; Türkmen et al., 2008; Singh et al., 2008; Waly et al., 2016), building materials (Alam et al., 2001; El-Khayatt, 2010; Salinas et al., 2006; Cay et al., 2014), glasses (El-Mallawany et al., 2017; Kumar et al., 2019, 2018; Sayyed, 2016; Sayyed et al., 2018), polymers (Aygün et al., 2015), rocks (Mahmoud et al., 2019; Obaid et al., 2018) and ores (Korkut et al., 2012).

Now it is necessary to look for cheap, economical, friendly and locally available shielding materials (Akkurt et al., 2010). Basalt is an igneous volcanic rock and it's the most widespread of all other igneous rocks, comprises more than $90 \%$ of all volcanic rocks. Basalt has very low level of radioactive content and considered as a good thermal insulator. Moreover, basalt rocks were reported to have high shielding properties as compared to other rocks (Mahmoud et al., 2019).

The present work deals with, measurement of the mass attenuation coefficient $\left(\mu_{\mathrm{m}}\right)$ for a mixture of micro size basalt powder, cement and sodium Meta silicate as a bond at a different pressure rate. The half value layer (HVL) and radiation protection efficiency (RF) were also calculated for the prepared concretes.

\section{Theory}

The gamma ray mass attenuation coefficient was measured for the prepared concretes using the narrow beam transmission method according to the Lambert Beer law (Obaid et al., 2018):

$I=I_{0} e^{\left(-\mu_{m} \rho t\right)}$

\footnotetext{
* Corresponding author. Ural Federal University, Yekaterinburg, 620002, Russia.

E-mail addresses: Kmahmud@urfu.ru, kareemabdelazeem@yahoo.com (K.A. Mahmoud).
} 
Where $I_{o}$ and $I$ are the incident and the transmitted gamma ray photon intensity, $t$ is the sample thickness, $\rho$ is the sample density and $\mu_{m}$ is the mass attenuation coefficient and equals to:

$\mu_{m}\left(\frac{\mathrm{cm}^{2}}{g}\right)=\frac{\mu\left(\mathrm{cm}^{-1}\right)}{\rho\left(\frac{\mathrm{g}}{\mathrm{cm}^{3}}\right)}$

Where $\mu$ is the linear attenuation coefficient. The mass attenuation coefficient for compound or mixture can be calculated theoretically through the relation (Sayyed, 2016):

$\mu_{m}=\sum_{i=1}^{n} \omega_{i}\left(\mu_{m}\right)_{i}$,

Where $\omega_{i}$ is the weight fraction and $\left(\mu_{m}\right)_{i}$ is the mass attenuation coefficient of ith constituent element respectively. The half value thickness (HVT) is an important parameter which described the attenuation process in term of the distance required for decreasing the intensity to half of its initial value and determined through the relation:

$H V T=\frac{\ln (2)}{\mu\left(\mathrm{cm}^{-1}\right)}$

The radiation protection efficiency of the studied materials from the relation:

$R p=\left(1-e^{\mu t}\right) * 100$

\section{Materials and methods}

The basalt samples used in this work were collected from south western Sinai, Egypt. The collected samples were crushed then sieved to different sizes using (HAVER EML 200 digital T) sieving. The environmental scanning electron microscope (ESEM) was used to identify the particle grain size of crushed basalt and cement as shown in Fig. 1 (a, b, c and d). The biggest particle grain size of the crushed basalt is shown in Fig (1-a) which represents the aggregates of G1 concretes. The particle grain size of G1 series of concretes is varied between (213$102 \mu \mathrm{m}$ ) with an average grain size $107 \mu \mathrm{m}$, while the smallest aggregates grin size (G3) illustrated in Fig (1-c) in which the particle size varied between (54.6-15.2 $\mu \mathrm{m})$ with average particle grain size $25 \mu \mathrm{m}$. Fig (1-b) represents the aggregates grain size of G3 series of concretes and it is clear that the particle grain size varied between $(102-42.7 \mu \mathrm{m})$ with an average grain size $71 \mu \mathrm{m}$. The particle grain size of the ordinary Portland cement used in preparation of our concretes is also measured and found to vary between $(5.52-2.73 \mu \mathrm{m})$ with an average grain size $4.1 \mu \mathrm{m}$.

Electronic balance (SARTORIUS AG GOTTINGEN) with detection limit $0.1 \mathrm{mg}$ was used to weigh $0.5 \mathrm{~g}$ of the concrete sample, then put in Teflon with $10 \mathrm{ml}$ hydrofluoric acid, few drops sulfuric acid and placed on a hot plate with temperature $250 \mathrm{C}$ till dry then dissolve the residue in $10 \mathrm{ml} \mathrm{HCL}$. The elemental analyses of the concrete sample were measured using inductively coupled plasma optical emission spectrometer (ICP-OES Prism, Teledyne Technologies) as shown in Table 1. The samples were injected to ICP- OES at the rate of $1.4 \mathrm{ml} / \mathrm{min}$ using a plastic pump to concentric Nebulizer with Argon (Ar) carrier gas pressure 34 psi carries the samples to an Axial cyclonic spray chamber with auxiliary or gas flow $0.1 \mathrm{l} / \mathrm{min}$ which make spray and atomization for the sample before entering the torch. A coolant (Ar) gas with a flow rate $18 \mathrm{ml} / \mathrm{min}$ was used to prevent the torch overheating (Nagdy et al., 2016).

Two series of concretes were prepared as a mixture of $75 \%$ crushed basalt (as aggregates), 25\% ordinary Portland cement and drops of sodium meta silicate. The first series consists of three concretes
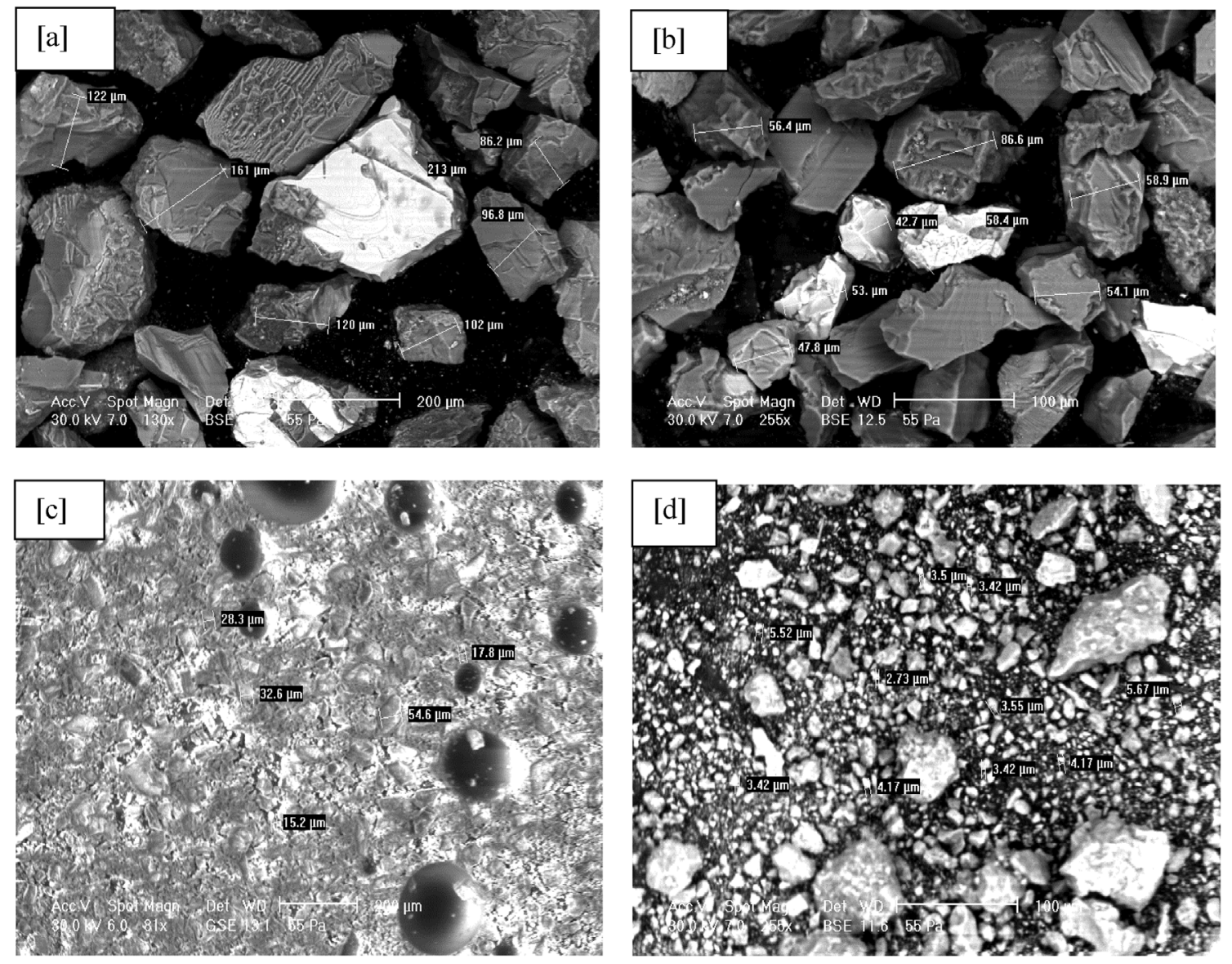

Fig. 1. ESEM imaging for [a] grain size G1, [b] grain size G2 and [c] grain size G3 and [d] cement grain size. 
Table 1

The elemental analysis of the studied sample.

\begin{tabular}{llll}
\hline Element & Weight fraction (\%) & \\
\hline $\mathrm{H}$ & 0.3689 & $\mathrm{Ca}$ & 7.0858 \\
$\mathrm{C}$ & 0.409 & $\mathrm{Ti}$ & 0.9683 \\
$\mathrm{O}$ & 30.8827 & $\mathrm{Mn}$ & 0.1547 \\
$\mathrm{Na}$ & 2.8608 & $\mathrm{Fe}$ & 7.8828 \\
$\mathrm{Mg}$ & $\mathrm{Ni}$ & 0.0048 \\
$\mathrm{Al}$ & $\mathrm{Sr}$ & 0.0463 \\
$\mathrm{Si}$ & $\mathrm{Zr}$ & 0.0168 \\
$\mathrm{P}$ & 5.8738 & $\mathrm{Ba}$ & 0.0367 \\
$\mathrm{~K}$ & 38.614 & & \\
\hline
\end{tabular}

Table 2

The density and mixture ratios of the prepared samples.

\begin{tabular}{lllll}
\hline Sample & $\begin{array}{l}\text { Average density } \\
\left(\mathrm{g} / \mathrm{cm}^{3}\right)\end{array}$ & $\begin{array}{l}\text { Cement ratio } \\
(\%)\end{array}$ & $\begin{array}{l}\text { Basalt ratio } \\
(\%)\end{array}$ & $\begin{array}{l}\text { Pressure rate }(\mathrm{kg} / \\
\left.\mathrm{cm}^{2}\right)\end{array}$ \\
\hline Normal & 1.836 & 25 & 75 & 1.01 \\
CS 30 & 1.8425 & 25 & 75 & 30.59 \\
CS 60 & 1.907 & 25 & 75 & 61.18 \\
CS 90 & 1.969 & 25 & 75 & 91.77 \\
CS 120 & 1.995 & 25 & 75 & 122.36 \\
CS 140 & 2.0132 & 25 & 75 & 142.76 \\
\hline
\end{tabular}

prepared with different basalt grain size. The prepared concretes were identified as G1, G2 and G3 with an average grain size 107, 71, $25 \mu \mathrm{m}$ and average density $1.81,1.74,1.77 \mathrm{gm} / \mathrm{cm}^{3}$ respectively. The second group consists of six concretes made up of the crushed basalt with grain size G3 (average grain size $25 \mu \mathrm{m}$ ), and with different press rate (1.01, $30.59,61.18,91.77,122.36$ and $142.76 \mathrm{~kg} / \mathrm{cm}^{2}$ ) using a hydraulic press using (DRAPER 10 ton with high pressure pump 10582). It can be seen that from Table 2. The compressed concretes were identified as Normal, CS30, CS60, CS90, CS120 and CS140 according to their press rate $1.01,30.59,61.18,91.77,122.36$ and $142.76 \mathrm{~kg} / \mathrm{cm}^{2}$ respectively.

The mass attenuation was measured using narrow beam transmission method as shown in Fig. 2. The prepared concretes were irradiated using gamma ray photons emitted from ${ }^{137} \mathrm{Cs}$ with energy $(661.6 \mathrm{KeV})$,

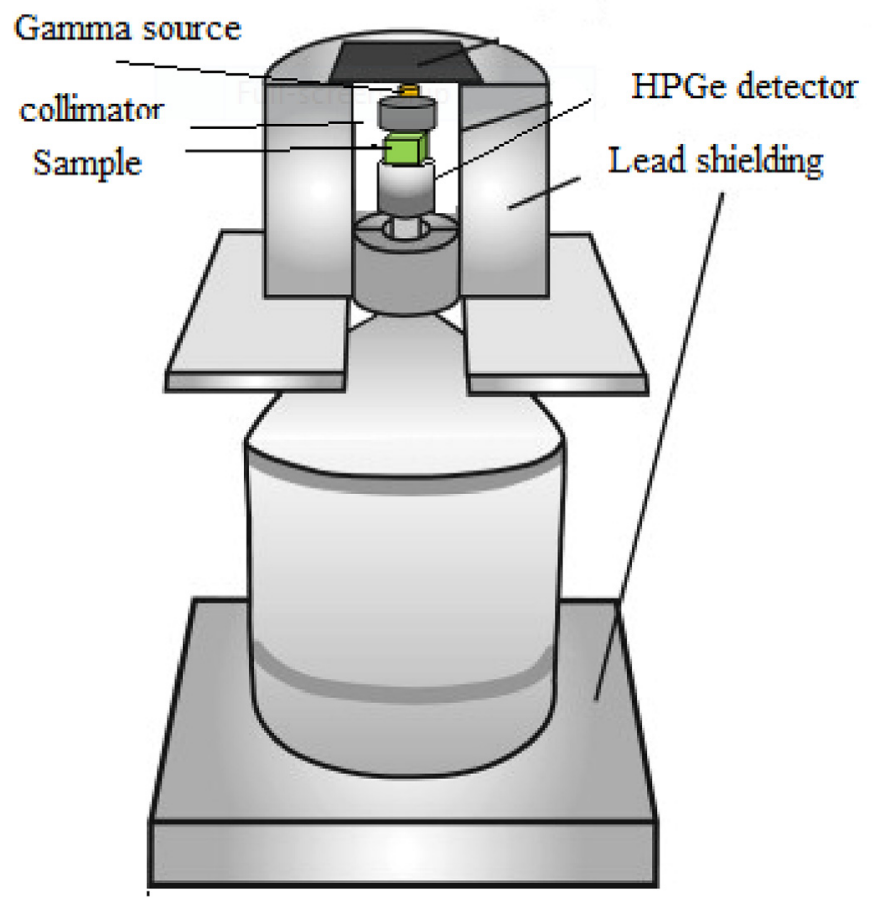

Fig. 2. Schematic diagram experimental measurements.

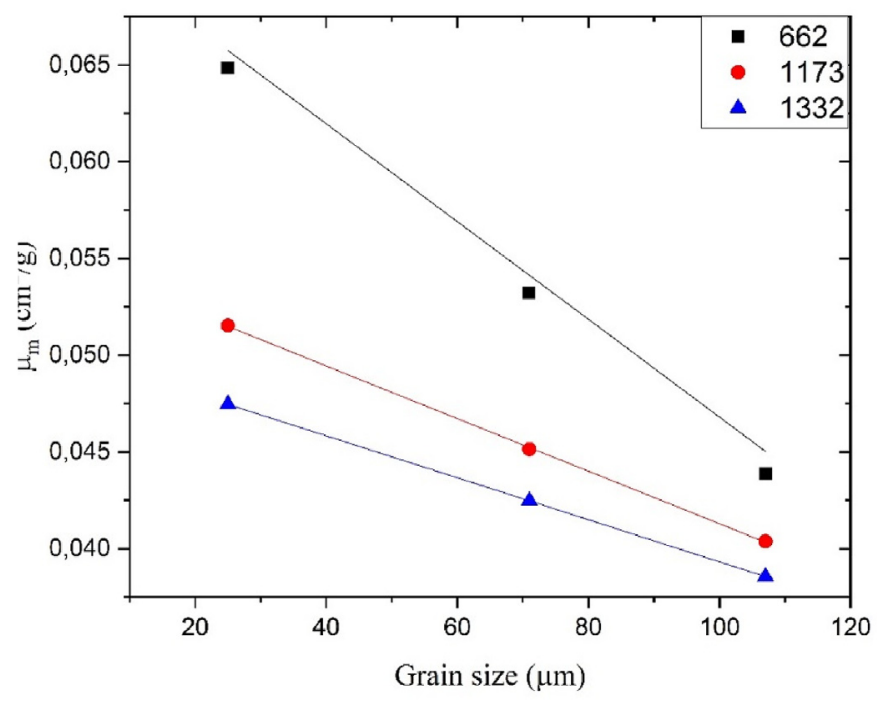

Fig. 3. The mass attenuation coefficient as a function of energy for different grain size.

${ }^{60} \mathrm{Co}$ with energies (1173.2 and $1332.5 \mathrm{KeV}$ ) and ${ }^{152} \mathrm{Eu}$ with energies (121.8, 244.7, 344.3, 778.9, 964, 1112 and $1408 \mathrm{KeV})$. The incident and transmitted intensities for ${ }^{137} \mathrm{Cs},{ }^{60} \mathrm{Co}$ and ${ }^{152} \mathrm{Eu}$ point sources were recorded using closed-end coaxial gamma-ray detector (n-type) made of high purity germanium (HPGe) in a vertical configuration (Pop Topcryostat configuration) cooled with liquid nitrogen. The used HPGe EG \&G Ortec Model GMX60P4 has a full width half maximum (FWHM) of $1.10 \mathrm{keV}$ at the $5.9 \mathrm{keV}$ gamma transition of ${ }^{55} \mathrm{Fe}$ and $2.3 \mathrm{keV}$ at the $1.33 \mathrm{MeV}$ gamma transition of ${ }^{60} \mathrm{Co}$.

\section{Results and discussion}

The mass attenuation coefficient was measured for two series of concretes made up of basalt aggregates have different grain size varied between 107 and $25 \mu \mathrm{m}$. The measured $\mu / \rho$ was plotted as a function of gamma ray energy as shown in Fig. 3 . It is clear that the mass attenuation coefficient decreases with the increase of gamma ray energy, while it is increasing with a decrease in grain size. In the present work, the $\mu / \rho$ attends to a maximum value for concrete G3 (average aggregate grain size $25 \mu \mathrm{m}$ ) and it is varied between 0.0648 and $0.0438 \mathrm{~cm}^{2} / \mathrm{g}$ between gamma energy 662 and $1332 \mathrm{KeV}$. The minimum $\mu / \rho$ obtained by concrete G1 (average aggregate grain size $107 \mu \mathrm{m}$ ). It is clear that the $\mu_{\mathrm{m}}$ for $\mathrm{G} 1$ series of concretes varied between 0.0385 and $0.0476 \mathrm{~cm}^{2} / \mathrm{g}$. It is seen from Fig. 3, that decreasing the basalt grain size increases the mass attenuation coefficient of the concrete (Malekie and Hajiloo, 2017). These are due to the internal distance between the particles and each other inside the concrete, where the distance between the particles and each other directly proportional with the grain size. Thus, the internal distance is small for small grain size particles which leads to a lot of collisions between the incident gamma ray and the concrete particles so the attenuation coefficient increase.

The mass attenuation coefficient was measured for six concretes performed as a mixture of basalt G3 (average grain size $25 \mu \mathrm{m}$ ), cement and drops of sodium meta silicate at different press rates. The measured data compared with theoretical data obtained from XCOM program (Berger et al., 2010), and plotted as a function of energy at different press rates as shown in Fig. 4. The experimental error was calculated for the prepared concretes and tabulated in Table 3.

In terms of XCOM database, we couldn't input the effect of pressure rate, so the mass attenuation calculation obtained from the XCOM program in this study were performed at normal pressure. Fig. 4 shows that the mass attenuation coefficient decreases with the gamma ray energy increase. Gamma ray with high energy have a low wavelength 


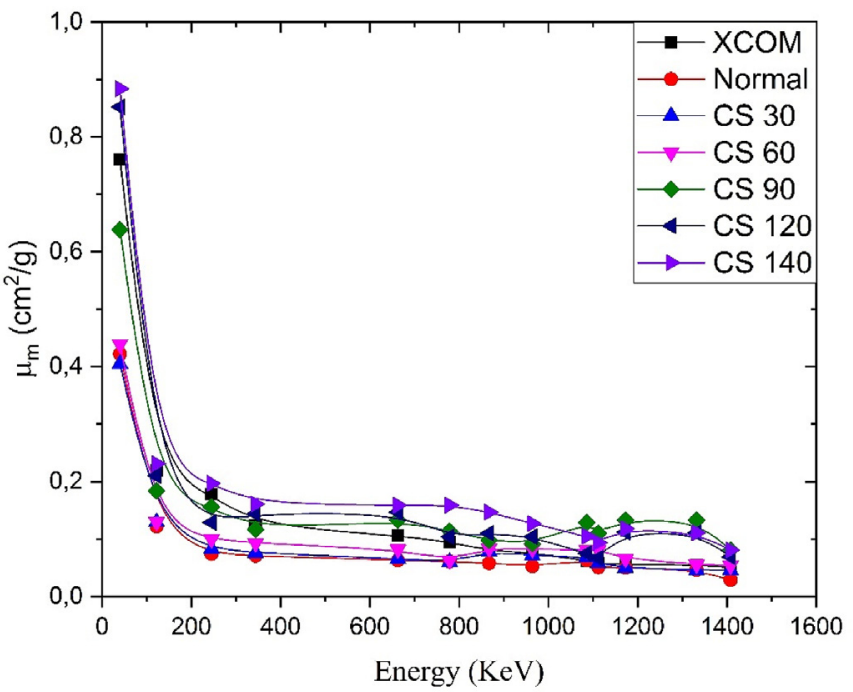

Fig. 4. The mass attenuation coefficient as a function of energy at different press rate.

and high penetrating power which lead to a little number of collisions with the concrete particles, thus the attenuation coefficient decreases. The measured mass attenuation coefficient for concretes normal, CS30 and CS60 shows agreement with obtained from XCOM. The agreement between experimental and theoretical data means that this pressure rates haven't significant effect on the mass attenuation coefficient of the prepared concretes at a low-pressure rate. On the other hand, the measured $\mu / \rho$ for the studied concretes illustrated in Fig. 4 showed a disagree with the theoretical data obtained from XCOM program for concerts CS 90, CS 120 and CS 140 . The experimental data showed a higher mass attenuation than the theoretical data. The disagreement between experimental and theoretical data is due to the pressure rate effects on the mass attenuation of prepared concretes. The $\mu / \rho$ attends to maximum for a concrete CS 140 and it varies between 0,884 and $0,884 \mathrm{~cm}^{2} / \mathrm{g}$ at an energy range between 40.11 and $1408 \mathrm{KeV}$ respectively. The minimum $\mu / \rho$ achieved in our study was obtained from concrete normal and varied between 0.422 and $0.029 \mathrm{keV}$ at an energy range between 40.11 and $1408 \mathrm{KeV}$ respectively.

The effect of concrete pressure rate on the mass attenuation coefficient was studied as shown in Fig. 5. It is clear that the mass attenuation coefficient increases with an increase in the concrete pressure rate of the studied gamma ray energy (Al-Humaiqani et al., 2013a,b). The $\mu / \rho$ attends to a maximum at a press rate $142.6 \mathrm{~kg} / \mathrm{cm}^{2}$ and its varied between 0.081 and $0.231 \mathrm{~cm}^{2} / \mathrm{g}$ at a gamma ray energy range between 1408 and $122.2 \mathrm{KeV}$, but the minimum $\mu / \rho$ was obtained at a

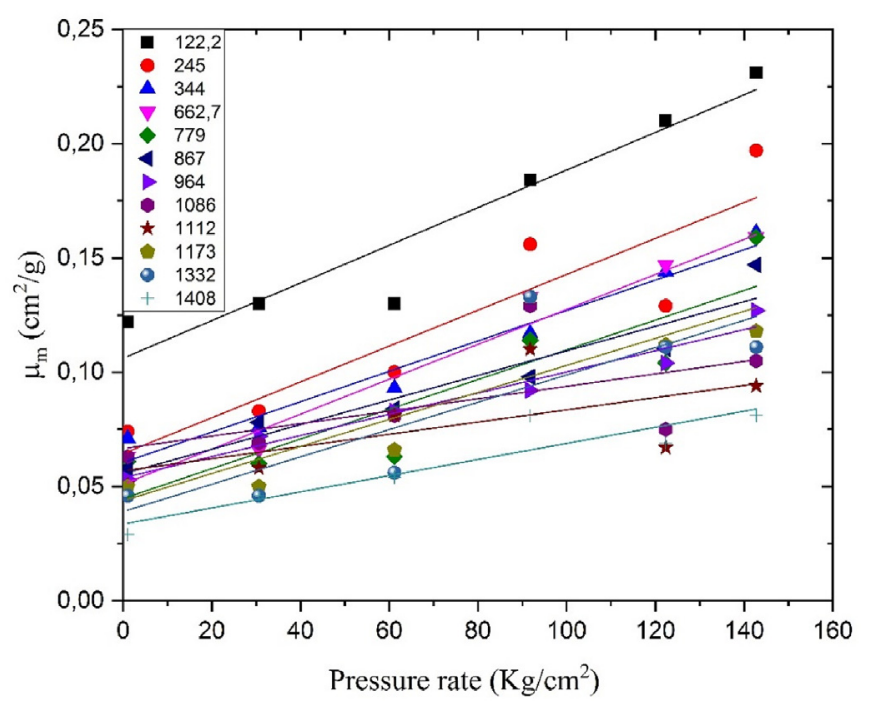

Fig. 5. The mass attenuation coefficient as a function of concrete compressive strength.

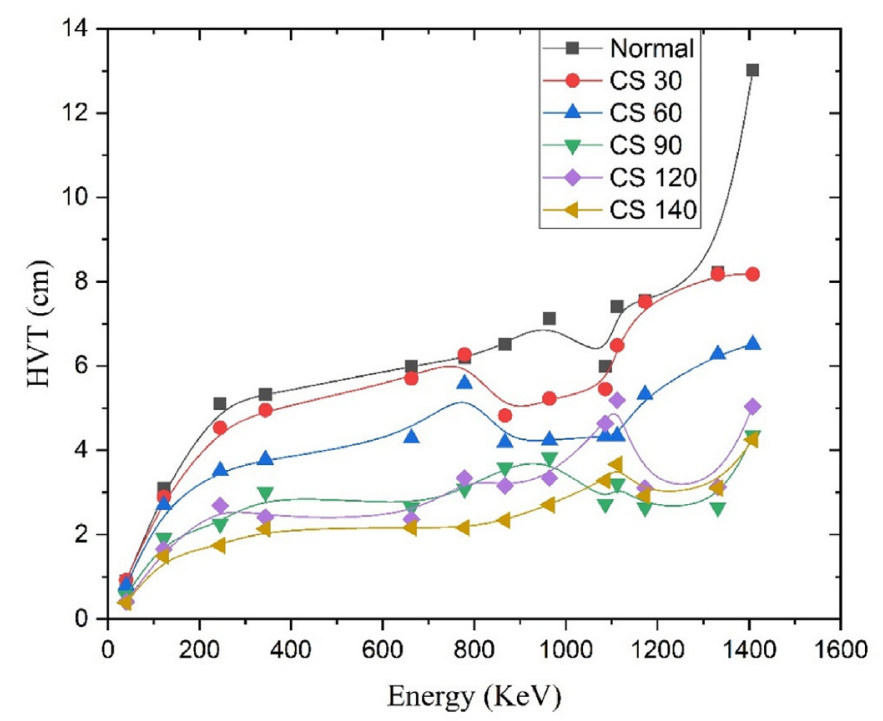

Fig. 6. The HVL of concerts at different press rate and at different energy.

Table 3

The mass attenuation coefficient and error ratios for the studied concretes.

\begin{tabular}{|c|c|c|c|c|c|c|c|}
\hline \multirow[t]{2}{*}{ Energy (keV) } & \multicolumn{7}{|c|}{ Mass attenuation coefficient $\left(\mathrm{cm}^{2} / \mathrm{g}\right)$} \\
\hline & Normal & CS 30 & CS 60 & CS 90 & CS 120 & CS 140 & $\mathrm{XCOM}$ \\
\hline 40,11 & $0,422 \pm 0004$ & $0,406 \pm 0007$ & $0,439 \pm 0005$ & $0,638 \pm 0007$ & $0,852 \pm 0009$ & $0,884 \pm 0009$ & 0,760 \\
\hline 122,2 & $0,122 \pm 0002$ & $0,130 \pm 0002$ & $0,130 \pm 0002$ & $0,184 \pm 0003$ & $0,210 \pm 0003$ & $0,231 \pm 0003$ & 0,219 \\
\hline 245 & $0,074 \pm 0003$ & $0,083 \pm 0005$ & $0,100 \pm 0003$ & $0,156 \pm 0005$ & $0,129 \pm 0005$ & $0,197 \pm 0007$ & 0,178 \\
\hline 344 & $0,071 \pm 0001$ & $0,076 \pm 0001$ & $0,093 \pm 0002$ & $0,117 \pm 0002$ & $0,144 \pm 0003$ & $0,161 \pm 0003$ & 0,124 \\
\hline 662 & $0,063 \pm 0002$ & $0,066 \pm 0001$ & $0,082 \pm 0002$ & $0,133 \pm 0003$ & $0,147 \pm 0003$ & $0,159 \pm 0003$ & 0,106 \\
\hline 779 & $0,061 \pm 0002$ & $0,06 \pm 0,001$ & $0063 \pm 0,002$ & $0114 \pm 0,004$ & $0104 \pm 0,003$ & $0159 \pm 0,005$ & 0095 \\
\hline 867 & $0,058 \pm 0004$ & $0,078 \pm 0006$ & $0,084 \pm 0006$ & $0,098 \pm 0007$ & $0.110 \pm 0,002$ & $0147 \pm 0,010$ & 0080 \\
\hline 964 & $0,053 \pm 0002$ & $0,072 \pm 0003$ & $0,083 \pm 0003$ & $0,092 \pm 0003$ & $0,104 \pm 0003$ & $0,127 \pm 0004$ & 0,076 \\
\hline 1086 & $0,063 \pm 0003$ & $0,069 \pm 0003$ & $0,081 \pm 0003$ & $0,129 \pm 0005$ & $0,075 \pm 0003$ & $0,105 \pm 0004$ & 0,062 \\
\hline 1112 & $0,051 \pm 0002$ & $0,058 \pm 0002$ & $0,081 \pm 0003$ & $0,110 \pm 0004$ & $0,067 \pm 0002$ & $0,094 \pm 0003$ & 0,058 \\
\hline 1173 & $0,050 \pm 0002$ & $0,050 \pm 0002$ & $0,066 \pm 0003$ & $0,133 \pm 0006$ & $0,112 \pm 0004$ & $0,118 \pm 0004$ & 0,056 \\
\hline 1332 & $0,046 \pm 0002$ & $0,046 \pm 0002$ & $0,056 \pm 0003$ & $0,133 \pm 0006$ & $0,111 \pm 0004$ & $0,111 \pm 0004$ & 0,055 \\
\hline 1408 & $0,029 \pm 0001$ & $0,046 \pm 0001$ & $0,054 \pm 0002$ & $0,081 \pm 0002$ & $0,069 \pm 0002$ & $0,081 \pm 0002$ & 0,051 \\
\hline
\end{tabular}




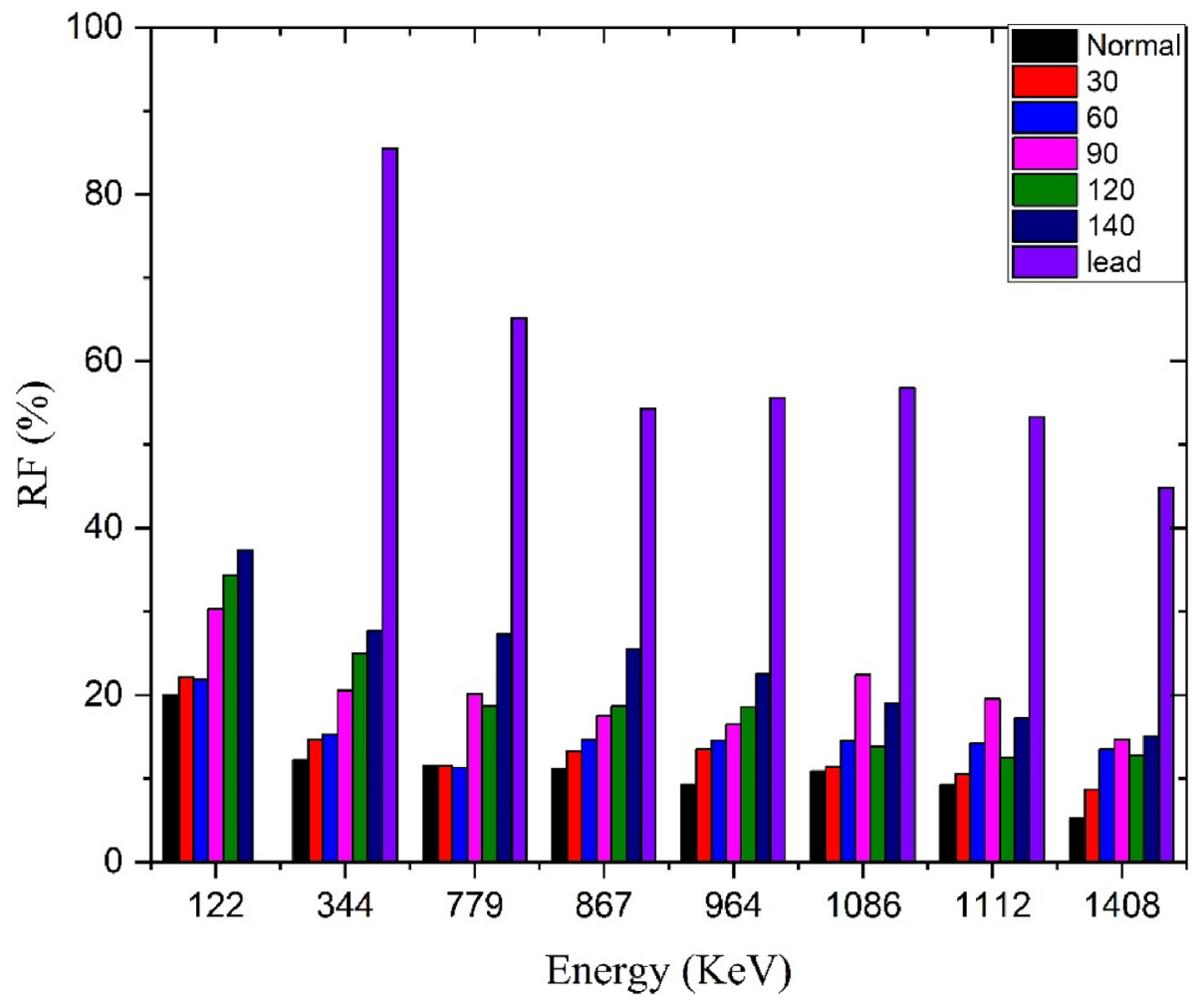

Fig. 7. The RF of the studied samples.

pressure rate $1.01 \mathrm{~kg} / \mathrm{cm}^{2}$ and varied between 0.029 and $0.122 \mathrm{~cm}^{2} / \mathrm{g}$ at a gamma energy range between 1408 and $122.2 \mathrm{KeV}$.

The Half value thickness (HVT) was calculated for the prepared concretes. The calculated results were plotted in Fig. 6, and shows that the HVT decreases with an increase in pressure rate. The highest HVT was obtained by concrete Normal and its varied between 0.89 and $13.02 \mathrm{~cm}$ in an energy range between 40.11 and $1408 \mathrm{KeV}$ and the lowest HVT was obtained by concrete CS140 and varied between 0.39 and $4.25 \mathrm{~cm}$ at an energy range between 40.11 and $1408 \mathrm{KeV}$. The press rate couldn't be increased over $140 \mathrm{~kg} / \mathrm{cm}^{2}$ because of a manual hydraulic was used.

The radiation protection efficiency (RF) was calculated for all studied concrete at different energy and compared to RF for lead. The calculated results plotted in Fig. 7 which shows that the RF increases with an increase in the pressure rate. The obtained results also show that the highest RF was obtained from concretes CS140 with RF about $33 \%$ which obtained by pure lead shielding materials.

\section{Conclusion}

Some shielding parameters were studied for two different types of concretes (concretes with different basalt grain size and concretes with different pressure rate). We can conclude that the $\mu_{\mathrm{m}}$ decreases with increase the incident gamma ray energy. Moreover, it is increased with decreasing the aggregate particle grain size at gamma ray energy $662-1332 \mathrm{KeV}$. The highest $\mu_{\mathrm{m}}$ was achieved for concrete series G3 (concretes with average aggregates grain size $25 \mu \mathrm{m}$ ) which is varied between 0.0648 and $0.0476 \mathrm{~cm}^{2} / \mathrm{g}$, while the lowest $\mu_{\mathrm{m}}$ is obtained by concrete series G3 (concretes with aggregates average grain size 107 $\mu_{\mathrm{m}}$ ) which is varied between 0.0385 and $0.0474 \mathrm{~cm}^{2} / \mathrm{g}$. Besides, the $\mu_{\mathrm{m}}$ for concretes with different pressure rate increases with increase the pressure rat between 122 and $1408 \mathrm{KeV}$. The $\mu_{\mathrm{m}}$ attends to maximum values for concretes CS 140 (concretes with pressure rate $142.6 \mathrm{~kg} / \mathrm{cm}^{2}$ ) which varied between 0.081 and $0.231 \mathrm{~m}^{2} / \mathrm{g}$ between incident gamma ray energy $122-1408 \mathrm{MeV}$. On the other hand, lowest $\mu_{\mathrm{m}}$ obtained for normal concretes (concretes with pressure rate $1.1 \mathrm{~kg} / \mathrm{cm}^{2}$ ) which varies between 0.029 and $0.122 \mathrm{~cm}^{2} / \mathrm{g}$. The RF factor was also calculated and showed that the pressure rate enhances the shielding properties of the cement-basalt concretes.

\section{Appendix A. Supplementary data}

Supplementary data to this article can be found online at https:// doi.org/10.1016/j.pnucene.2019.103092.

\section{References}

Akkurt, I., Kilincarslan, S., Basyigit, C., 2004. The photon attenuation coefficients of barite, marble and limra. Ann. Nucl. Energy. https://doi.org/10.1016/j.anucene. 2003.07.002.

Akkurt, I., Akyýldýrým, H., Mavi, B., Kilincarslan, S., Basyigit, C., 2010. Photon attenuation coefficients of concrete includes barite in different rate. Ann. Nucl. Energy 37, 910-914. https://doi.org/10.1016/j. anucene.2010.04.001.

Al-Humaiqani, M.M., Shuraim, A.B., Hussain, R.R., 2013a. $\gamma$-Radiation shielding properties of high strength high performance concretes prepared with different types of normal and heavy aggregates. Asian Trans. Eng. 03, 18-28.

Al-Humaiqani, Mohammed M., Shuraim, Ahmed B., R.R.H, 2013b. Effect of compressive strength on $\gamma$-radiation attenuation coefficients for high performance concrete. IACSIT Int. J. Eng. Technol. 5, 566-572. https://doi.org/10.7763/IJET.2013.V5.619.

Alam, M.N., Miah, M.M.H., Chowdhury, M.I., Kamal, M., Ghose, S., Rahman, R., 2001. Attenuation coefficients of soils and some building materials of Bangladesh in the energy range 276-1332 keV. Appl. Radiat. Isot. 54, 973-976. https://doi.org/10. 1016/S0969-8043(00)00354-7.

Aygün, B., Korkut, T., Karabulut, A., Gencel, O., Karabulut, A., 2015. Production and neutron irradiation tests on a new epoxy/molybdenum composite. Int. J. Polym. Anal. Charact. 20, 323-329. https://doi.org/10.1080/1023666X.2015.1017790.

Bashter, I.I., 1997. Calculation of radiation attenuation coefficients for shielding concretes. Ann. Nucl. Energy 24, 1389-1401. https://doi.org/10.1016/S0306-4549(97) 00003-0.

Bashter, I.I., Makarious, A.S., Abdo, E.S., 1996. Investigation of hematite-serpentine and ilmenite-limonite concretes for reactor radiation shielding. Ann. Nucl. Energy 23, 65-71. https://doi.org/10.1016/0306-4549(95)00011-G.

Berger, M.J., Hubbell, J.H., Seltzer, S.M., Chang, J., Coursey, J.S., Sukumar, R., Zucker, D.S., K.O, 2010. XCOM:Photon Cross Section Database. Natl. Inst. Stand. Technol., Gaithersburg, MD [Online]. https://doi.org/10.18434/T48G6X, version 1.5.

Cay, V.V., Sutcu, M., Gencel, O., Korkut, T., 2014. Neutron radiation tests about FeCr slag and natural zeolite loaded brick samples. Sci. Technol. Nucl. Install. 2014, 1-5. 
https://doi.org/10.1155/2014/971490

El-Khayatt, A.M., 2010. Radiation shielding of concretes containing different lime/silica ratios. Ann. Nucl. Energy 37, 991-995. https://doi.org/10.1016/j.anucene.2010.03. 001.

El-Mallawany, R., Sayyed, M.I., Dong, M.G., 2017. Comparative shielding properties of some tellurite glasses: Part 2. J. Non-Cryst. Solids 474, 16-23. https://doi.org/10. 1016/j.jnoncrysol.2017.08.011.

El-Sayed Abdo, A., 2002. Calculation of the cross-sections for fast neutrons and gammarays in concrete shields. Ann. Nucl. Energy 29. https://doi.org/10.1016/S03064549(02)00019-1 1977-1988.

Gencel, O., Bozkurt, A., Kam, E., Korkut, T., 2011. Determination and calculation of gamma and neutron shielding characteristics of concretes containing different hematite proportions. Ann. Nucl. Energy 38, 2719-2733. https://doi.org/10.1016/j. anucene.2011.08.010.

Gençel, O., Naziroglu, M., Çelik, Ö., Yalman, K., Bayram, D., 2010. Selenium and vitamin e modulates radiation-induced liver toxicity in pregnant and nonpregnant rat: effects of colemanite and hematite shielding. Biol. Trace Elem. Res. 135, 253-263. https:// doi.org/10.1007/s12011-009-8513-8.

Kharita, M.H., Takeyeddin, M., Alnassar, M., Yousef, S., 2008. Development of special radiation shielding concretes using natural local materials and evaluation of their shielding characteristics. Prog. Nucl. Energy 50, 33-36. https://doi.org/10.1016/j. pnucene.2007.10.004.

Korkut, T., Karabulut, A., Budak, G., Aygün, B., Gencel, O., Hançerlioĝullari, A., 2012. Investigation of neutron shielding properties depending on number of boron atoms for colemanite, ulexite and tincal ores by experiments and FLUKA Monte Carlo simulations. Appl. Radiat. Isot. 70, 341-345. https://doi.org/10.1016/j.apradiso.2011. 09.006.

Kumar, A., Sayyed, M.I., Dong, M., Xue, X., 2018. Effect of PbO on the shielding behavior of ZnO-P2O5 glass system using Monte Carlo simulation. J. Non-Cryst. Solids 481, 604-607. https://doi.org/10.1016/j.jnoncrysol.2017.12.001.

Kumar, A., Gaikwad, D.K., Obaid, S.S., Tekin, H.O., Agar, O., Sayyed, M.I., 2019. Experimental studies and Monte Carlo simulations on gamma ray shielding competence of $(30+\mathrm{x}) \mathrm{PbO} 10 \mathrm{WO} 310 \mathrm{Na} 2 \mathrm{O}-10 \mathrm{MgO}-(40-\mathrm{x}) \mathrm{B} 2 \mathrm{O} 3$ glasses. Prog. Nucl. Energy 103047. https://doi.org/10.1016/j.pnucene.2019.103047.

Mahmoud, K.A., Sayyed, M.I., Tashlykov, O.L., 2019. Gamma ray shielding characteristics and exposure buildup factor for some natural rocks using MCNP-5 code. Nucl. Eng. Technol. https://doi.org/10.1016/j.net.2019.05.013.

Malekie, S., Hajiloo, N., 2017. Comparative study of micro and nano size WO3/E44 epoxy composite as gamma radiation shielding using MCNP and experiment. Chin. Phys. Lett. 34, 2-4. https://doi.org/10.1088/0256-307X/34/10/108102.

Mann, H.S., Brar, G.S., Mann, K.S., Mudahar, G.S., 2016. Experimental investigation of clay fly ash bricks for gamma-ray shielding. Nucl. Eng. Technol. 48, 1230-1236. https://doi.org/10.1016/j.net.2016.04.001.
Nagdy, M.S. El, Ali, B.H., Wakil, A.F. El, Gaber, K.A., 2016. Effect of physical parameters in measuring some poisonous and radionuclides in groundwater using ICP-OES : a case study in southwestern Sinai , Egypt. Arab J. Nucl. Sci. Appl. 49, 74-84.

Obaid, S.S., Sayyed, M.I., Gaikwad, D.K., Pawar, P.P., 2018. Attenuation coefficients and exposure buildup factor of some rocks for gamma ray shielding applications. Radiat. Phys. Chem. 148, 86-94. https://doi.org/10.1016/j.radphyschem.2018.02.026.

Rezaei-Ochbelagh, D., Azimkhani, S., 2012. Investigation of gamma-ray shielding properties of concrete containing different percentages of lead. Appl. Radiat. Isot. 70, 2282-2286. https://doi.org/10.1016/j.apradiso.2012.06.020.

Salinas, I.C.P., Conti, C.C., Lopes, R.T., 2006. Effective density and mass attenuation coefficient for building material in Brazil. Appl. Radiat. Isot. 64, 13-18. https://doi. org/10.1016/j.apradiso.2005.07.003.

Sayyed, M.I., 2016. Half value layer, mean free path and exposure buildup factor for tellurite glasses with different oxide compositions. J. Alloys Compd. https://doi.org/ 10.1016/j.jallcom.2016.11.318.

Sayyed, M.I., Lakshminarayana, G., Dong, M.G., Ersundu, M.C., Ersundu, A.E., Kityk, I.V , 2018. Investigation on gamma and neutron radiation shielding parameters for $\mathrm{BaO} /$ SrO-Bi 2 O 3 -B 2 O 3 glasses. Radiat. Phys. Chem. 145, 26-33. https://doi.org/10. 1016/j.radphyschem.2017.12.010.

Shirmardi, S.P., Shamsaei, M., Naserpour, M., 2013. Comparison of photon attenuation coefficients of various barite concretes and lead by MCNP code, XCOM and experimental data. Ann. Nucl. Energy 55, 288-291. https://doi.org/10.1016/j.anucene. 2013.01.002.

Singh, C., Singh, T., Kumar, A., Mudahar, G.S., 2004. Energy and chemical composition dependence of mass attenuation coefficients of building materials. Ann. Nucl. Energy 31, 1199-1205. https://doi.org/10.1016/j.anucene.2004.02.002.

Singh, S., Kumar, A., Singh, D., Thind, K.S., Mudahar, G.S., 2008. Barium-borate-flyash glasses: as radiation shielding materials. Nucl. Instrum. Methods Phys. Res. Sect. B Beam Interact. Mater. Atoms 266, 140-146. https://doi.org/10.1016/j.nimb.2007. 10.018 .

Singh, K., Singh, S., Dhaliwal, A.S., Singh, G., 2015. Gamma radiation shielding analysis of lead-flyash concretes. Appl. Radiat. Isot. 95, 174-179. https://doi.org/10.1016/j. apradiso.2014.10.022.

Türkmen, I., Özdemir, Y., Kurudirek, M., Demir, F., Simsek, Ö., Demirboǧa, R., 2008. Calculation of radiation attenuation coefficients in Portland cements mixed with silica fume, blast furnace slag and natural zeolite. Ann. Nucl. Energy 35, 1937-1943. Contents. https://doi.org/10.1016/j.anucene.2008.03.012.

Waly, E.S.A., Fusco, M.A., Bourham, M.A., 2016. Gamma-ray mass attenuation coefficient and half value layer factor of some oxide glass shielding materials. Ann. Nucl. Energy 96, 26-30. https://doi.org/10.1016/j.anucene.2016.05.028.

Yılmaz, E., Baltas, H., E.K, Ustabas, I., Cevik, U., A.M.E.-K, 2011. Gamma ray and neutron shielding properties of some concrete materials. Ann. Nucl. Energy 38, 2204-2212. Contents. https://doi.org/10.1016/j.anucene.2011.06.011. 